\title{
Kecakapan Bertindak Penyandang Disabilitas Autisme Menurut Hukum Perdata
}

\author{
Abdul Hariss*, Nur Fauzia \\ Fakultas Hukum Universitas Batanghari \\ *Correspondence email: abdulhariss94660@gmail.com
}

\begin{abstract}
Abstrak. Seseorang penyandang disabilitas memiliki hak untuk diperlakukan sama dengan subjek hukum manusia lainnya. Oleh karena itu, pemerintah berkewajiban untuk mewujudan hak-hak yang tercantum dalam konvensi, menggunakan peraturan perundang-undangan, termasuk cara memenuhi hak-hak penyandang disabilitas dalam setiap aspek kehidupan seperti : penghidupan yang layak, pendidikan, kesehatan dan lain sebagainya sama seperti manusia yang normal lainnya. Seorang autis atau yang dalam istilah psikologi disebut autisme, termasuk dalam kategori seorang penyandang disabilitas mental. Seseorang dikatakan autisme jika mengalami ketidaknormalan dalam melakukan suatu perbuatan hukum, perkembangan dalam hal kualitas kesanggupan melakukan hubungan sosial dan emosional dalam lingkungan hidup sosial masyarakat. Seseorang dikatakan menyandang autisme yaitu seseorang yang memiliki karakter khusus pada orang seumumnya tidak dengan memperlihatkan pada ketidaksanggupan mental (psikis), emosi (afeksi) atau fisik (jasmani). Kata autis yakni "auto" berarti maka semua yang terarah pada perseorangan. Menurut keterangan yang tidak sulit dipahami, autisme ialah suatu ketidaknormalan pada otak yang menyebabkan berkurangnya atau hilangnya kesanggupan seseorang untuk melakukan komunikasi, berkaitan pada sesama dan tanggapan yang diberikan pada sekitar atau lingkungannya.
\end{abstract}

Kata kunci: Kecakapan Bertindak; Disibalitas; Autisme

Abstract. A person with a disability has the right to be treated the same as other human legal subjects. Therefore, the government is obliged to realize the rights listed in the convention, using laws and regulations, including how to fulfill the rights of persons with disabilities in every aspect of life such as: a decent living, education, health and so on, just like humans who live with disabilities. other normal. An autistic person or what in psychological terms is called autism, is included in the category of a person with a mental disability. A person is said to be autistic if he experiences abnormalities in carrying out a legal act, development in terms of the quality of the ability to carry out social and emotional relationships in the social environment of the community. A person is said to have autism, namely someone who has a special character in people generally not by showing mental (psychic), emotional (affective) or physical (physical) disabilities. The word autism, namely "auto" means everything that is directed at the individual. According to information that is not difficult to understand, autism is an abnormality in the brain that causes a decrease or loss of a person's ability to communicate, relate to others and respond to the environment or environment.

Keywords: Acting Skills; Disability; Autism

\section{PENDAHULUAN}

Negara Republik Indonesia yang berdasarkan Pancasila dan Undang-Undang Dasar Negara Republik Indonesia Tahun 1945 (UUDS 1945) mengakui dan menaati serta menjunjung tinggi derajat dan tingkat harkat kemanusiaan. Hak dasar yang secara kodrat terikat pada pribadi manusia itulah dikatakan hak asasi manusia, memiliki sifat umum dan kekal, juga terlindungi, dimuliakan, dan dipegang teguh oleh Negara Republik Indonesia (RI), sampai menjadi tempat berlindung dan cara memajukan hak asasi manusia kepada kumpulan orang rentan terkhusus orang yang menyandang disabilitas perlu dilakukan peningkatan. ${ }^{1}$

Pada Tanggal 13 Desember Tahun 2006 Majelis Umum Perserikatan Bangsa-Bangsa (PBB) telah mengeluarkan Resolusi Nomor A/61/106 mengenai Konvensi tentang Hak-Hak Penyandang Disabilitas

${ }^{1}$ Penjelasan atas konsideran dalam Undang-Undang Nomor 19 tahun 2011 tentang Pengesahan Convention On The Rights Of Person With Disabilities (Konvensi mengenai HakHak Penyandang Disabilitas).
(Convention on the Rights of Persons with Disabilities). Menurut Resolusi PBB ini, orang yang menyandang disabilitas ialah sebagai orang yang tidak sanggup menanggung oleh pribadinya sendiri, semua atau beberapa, yang dibutuhkan perseorangan normal dan/atau aktifitas sosial, sebagai hasil dari kekurangan mereka, baik itu sifat yang dibawa sejak lahir ataupun bukan, pada hal kesanggupan fisik atau mentalnya.

Konvensi bertujuan sebagai pemajuan, pelindung dan menanggung seluruh hak asasi manusia dan kebebasan fundamental bagi seluruh orang yang menyandang disabilitas dan guna melakukan peningkatan pemberian hormat atas tingkat harkat kemanusiaan yang melekat pada mereka. Pada Tanggal 30 Maret Tahun 2007 Pemerintah Indonesia secara resmi menandatangani konvensi ini di New York.

Selanjutnya, pada Tanggal 10 November 2011 Pemerintah Indonesia menandatangani dan mengesahkan konvensi tersebut dengan menerbitkan Undang-Undang Nomor 19 Tahun 2011 tentang Pengesahan Konvensi Hak-Hak Penyandang Disabilitas. Hal ini 
memperlihatkan kesungguhan dan komitmen Pemerintah Indonesia untuk menaruh rasa hormat, memberi rasa dilindungi dan menunaikan hak orang yang menyandang disabilitas dengan harapan pada akhirnya menaikkan taraf kesejahteraan seseorang penyandang disabilitas.

Oleh sebab itu orang yang menyandang disabilitas mempunyai hak untuk lepas dari perlakuan yang kejam atau penyiksaan, tidak memiliki rasa kemanusiaan, menganggap rendah harga diri manusia, lepas dari pemerasan (eksploitasi), kekejaman dan perlakuan semena-mena, serta mempunyai hak untuk memperoleh pemberian hormat atas mutu mental dan fisiknya menurut kesamaan dengan orang lain, termasuk di dalamnya hak untuk memperoleh rasa dilindungi dan bantuan sosial dalam rencana kemandirian, serta dalam kondisi mendesak.

Tanggal 15 April Tahun 2016 Pemerintah Indonesia menindaklanjuti ratifikasi dari konvensi tersebut dengan memberlakukan rencana dalam UndangUndang Perihal Orang Yang Menyandang Disabilitas menjadi Undang-Undang Nomor 8 Tahun 2016 tentang Orang Yang Menyandang Disabilitas (selanjutnya disingkat UUPD) dalam Lembaran Negara Tahun 2016 Nomor 69. UUPD ini sekaligus membatalkan dan membuat pernyataan bahwa Undang-Undang No. 4 Tahun 1997 tentang Orang yang menderita ketidaknormalan/kurang normal tidak berlaku lagi.

Menurut Pasal 1 UUPD yang dimaksud sebagai orang yang menyandang (menderita) disabilitas, yakni : penyandang yang menderita disabilitas ialah diantara beberapa orang yang menjalani (mengalami) fisik terbatas, intelektual, mental, dan/atau sensorik dalam jangka waktu lama yang dalam melakukan hubungan dengan sekitar bisa terhambat dan sulit untuk berpartisipasi secara penuh dan efektif dengan warga negara lainnya berdasarkan kesamaan hak".

Berdasarkan definisi dari ketentuan ini, penyandang disabilitas diklasifikasikan menjadi 4 (empat) Pasal 4 ayat 1 berikut;

1. Jenis/Laku Orang Yang Menyandang (Menderita) Disabilitas yaitu:
a. Orang Yang Menyandang Disabilitas Jasmani (fisik);
b. Orang Yang Menyandang Disabilitas Ilmu Pengetahuan (intelektual);
c. Orang Yang Menyandang Disabilitas Batin (mental); dan/atau
d. Orang Yang Menyandang Disabilitas Sensorik.

2. Jenis/Laku Orang Yang Menyandang (Menderita) Disabilitas yang dimaksud pada ayat (1) bisa terjadi secara sendiri, berpasangan, atau bermacam-macam dalam jangka waktu lama yang ditentukan oleh tenaga medis menurut ketetapan perundangundangan.

Salah satu kategori orang menyandang disabilitas mental adalah autisme, sebagaimana yang disebutkan dalam UUPD pada bagian Penjelasan Pasal 4 ayat (1) huruf c bahwa: Maksud dari "Orang Yang Menyandang (Menderita) Disabilitas Mental" ialah adanya ketidaknormalan yang terjadi pada kegunaan cara berpikir, emosi, dan tingkah laku, diantaranya yakni:

1. Psikososial di antaranya skizofrenia, bipolar, depresi, anxietas, dan ketidaknormalan kepribadian; dan

2. Disabilitas perkembangan yang akan mempengaruhi pada kesanggupan hubungan sosial di antaranya autis dan hiperaktif.

Berdasarkan ketentuan ini, autis atau yang dalam istilah psikologi disebut autisme ini, termasuk ke dalam kategori seseorang penyandang disabilitas mental. Seseorang termasuk dikatakan autisme jika ia mengalami ketidaknormalan pada perkembangan perihal tingkat baik buruknya kepandaian hubungan sosial dan emosional, komunikasi, dan kesanggupan yang kurang dalam minat disertai pengulangan gerak-gerak tanpa tujuan. $^{2}$

Orang yang dikatakan menyandang (menderita) autisme yaitu seseorang yang memiliki karakter sendiri (berkarakter khusus) lain pada orang seumumnya tidak dengan memperlihatkan pada ketidaksanggupan psikis (mental), afeksi (emosi) atau jasmani (fisik). Autis berasal dari kata "auto" yang berarti maka semua yang mengarah pada perseorangan. ${ }^{3}$ Pendefinisian yang tidak susah (mudah) dipahami, autisme merupakan hal menyebabkan ketidaknormalan pada otak yang berakibat kemampuan seseorang berkurang untuk melakukan komunikasi, melakukan hubungan dengan sesama dan tanggapan yang diberi pada sekitar (lingkungannya). ${ }^{4}$

Di antara kepunyaan (hak-hak) orang yang menyandang disabilitas teratur pada UUPD dimuat Pasal 9 yang menerangkan bahwa hak perlakuan adil dan hak hukum tempat berlindung orang yang menyandang disabilitas yakni hak:

a. Atas perbuatan yang sama di hadapan hukum;

b. Ditetapkan sebagai subjek hukum;

c. Mempunyai dan memperoleh warisan harta bergerak atau tidak bergerak;

d. Menguasai kendali perihal keuangan atau menentukan seseorang guna menjadi wakil dalam persoalan keuangan dan kepentingannya;

${ }^{2}$ M. Sugiarmin, Bahan Ajar tentang Anak Autis, Fakultas Pendidikan Luar Biasa Universitas Pendidikan Indonesia, Jakarta, 2005, Hal. 9.

${ }^{3}$ Dalam Kamus Lengkap Psikologi, Autisme didefinisikan sebagai (1) cara berpikir yang dikendalikan oleh kebutuhan personal atau oleh diri sendiri, (2) menanggapi dunia berdasarkan penglihatan dan harapan sendiri, menolak realitas, dan (3) keasyikan ekstrim dengan pikiran dan fantasi sendiri, Chaplin, 2005, Hal. 46.

${ }^{4}$ Hartono, B., Aspek Neurologik Autisme Infantil. Seminar \& Work-shop on Fragile-X Mental Retardation, Autism and Related Disorders, Universitas Diponegoro, Semarang, 2002, Hal. 27. 
e. Mendapat akses pada perihal melayani jasa perbankan dan nonperbankan;

f. Mendapat ketersediaan aksesibilitas dalam pelayanan peradilan; pada pelaksanaan melindungi dari semua paksaan, kekejaman, perbuatan menganiaya, diskriminasi, dan/atau penyitaan atau pengalihan hak milik;

g. Menentukan orang untuk mewakili kepentingannya dalam hal keperdataan di dalam dan di luar pengadilan; dan

h. Memperoleh perlindungan atas hak kekayaan intelektualnya.

Definisi perihal kesanggupan tidak terurai dengan jelas di dalam Kitab Undang-Undang Hukum Perdata (KUHPerdata). Tidak ada pengklasifikasian mengenai seorang yang sanggup (cakap) dalam hukum, yang ada hanya tentang ketidakcakapan, sebagaimana yang dimuat dalam pasal 1330 KUHPerdata, bahwa yang dimaksud tidak cakap, antara lain:

1. Orang-orang yang belum sampai umur (kanakkanak);

2. Mereka yang sedang di taruh di bawah pengampuan;

3. Perempuan, dalam hal-hal yang ditentukan undangundang, dan pada umumnya semua orang yang oleh undang-undang dilarang untuk membuat persetujuan tertentu. Perbandingan yang dipakai dalam penilaian rancangan dan standar cakap ialah silogisme dari apa yang dikatakan dalam Pasal 1330 KUHPerdata di atas, dikatakan sebagai orang yang sanggup (cakap) yakni yang bisa melakukan pernyataan setuju dengan dasar penilaian sudah cukup umur (dewasa) dan bukan berada pada pengampuan. Sehingga dapatlah disimpulkan bahwa kesanggupan (kemampuan) dalam melakukan tindakan adalah kemampuan melakukan suatu perbuatan hukum yang menyatakan setuju (kesepakatan) dengan syarat sudah cukup umur (dewasa) dan bukan berada pada pengampuan.

Dari sisi lain UUPD Pasal 9 secara implisit mengakui bahwa orang yang menyandang disabilitas autisme sebagai pokok subyek hukum dan mempunyai bermacam hak keperdataan seperti manusia pada umumnya. Sedangkan penyandang disabilitas autisme pada umumnya adalah subjek yang sedang berada di bawah pengampuan orang lain, Sehingga apabila mengacu pada ketentuan ini, maka penyandang disabilitas dapat dikategorikan tidak sanggup untuk melakukan perbuatan hukum perdata atau privat, karena berada di bawah pengampuan orang lain.

Persamaan konsep kecakapan bertindak antara Undang-Undang Nomor 8 Tahun 2016 tentang penyandang disabilitas dan KUHPerdata menimbulkan kontradiksi dengan semangat perlindungan hukum atas hak penyandang disabilitas yang dilindungi oleh UUPD itu sendiri, khususnya hak keperdataan bagi penyandang disabilitas autisme, karena secara teoritis menjadi kendala bagi penyandang disabilitas autisme untuk menjalankan atau melaksanakan secara langsung (mandiri) hak-hak keperdataan yang dimilikinya seperti manusia normal lain pada umumnya.

\section{Rumusan Masalah}

Berdasarkan latarbelakang yang telah jelaskan sebelumnya, maka dirumuskan masalah sebagai berikut:

1. Bagaimanakah kriteria kecakapan bertindak bagi penyandang disabilitas autisme menurut hukum perdata?

2. Apakah akibat hukum atas perbuatan yang dilakukan oleh seorang penyandang disabilitas sebagai subjek hukum perdata?

\section{METODE}

Penelitian hukum merupakan suatu kegiatan ilmiah, yang didasarkan pada metode, sistematika dan pemikiran tertentu, yang bertujuan untuk mempelajari sesuatu atau beberapa gejala hukum tetentu dengan jalan menganalisanya. ${ }^{5}$

\section{Pendekatan Penelitian}

Pada penelitian ini penulis akan menggunakan beberapa Pendekatan, antara lain; Pendekatan Konseptual (Conceptual Approach), yaitu penelitian hukum kepustakaan sebagai suatu kajian yang dilakukan dengan menelaah bahan pustaka dan mempelajari aturan terkait "Kriteria Kecakapan Bertindak Penyandang Disabilitas Autisme Menurut Hukum Perdata”.

\section{Spesifikasi Penelitian}

Penelitian dalam penulisan hukum ini tergolong sebagai penelitian hukum normatif, penelitian hukum normatif adalah penelitian hukum yang meletakkan hukum sebagai sebuah bangunan sistem norma. Sistem norma yang dibangun adalah mengenai asas-asas, norma, kaidah dari peraturan perundangan, putusan pengadilan, peranjian, serta doktrin (ajaran). ${ }^{6}$ Penelitian ini dilakukan dengan maksud untuk memberikan argumentasi hukum sebagai dasar penentu apakah suatu peristiwa telah benar atau salah serta bagaimana sebaiknya peristiwa itu menurut hukum. ${ }^{7}$

\section{Sumber Bahan Hukum}

Penelitian yang akan penulis lakukan termasuk dalam kategori penelitian normatif atau disebut juga sebagai penelitian kepustakaan (library research), sehingga bahan yang digunakan adalah bahan hukum Pustaka atau Data Sekunder, yang terdiri dari:

${ }^{5}$ Zainuddin Ali, Metode Penelitian Hukum, Jakarta, Sinar Grafika, Edisi ke -1, Cetakan ke-5, 2009, Hal. 18.

6 Mukti Fajar dan Yulianto Achmad, Dualisme Penelitian Hukum Normatif dan Empiris,Cetakan IV, Yogyakarta, Pustaka Pelajar, 2007,Hal.33.

${ }^{7}$ Ibid, Hal. 36. 
1. Bahan hukum Primer, yaitu bahan hukum yang mengikat, diantaranya Peraturan Perundangundangan. Dalam penelitian ini, Peraturan Perundang-Undangan yang digunakan, antara lain : Undang-Undang Dasar Negara Republik Indonesia tahun 1945, KUH Perdata, Undang-Undang Nomor 8 Tahun 2016 tentang Penyandang Disabilitas.

2. Bahan hukum Sekunder, yaitu bahan hukum yang memberikan penjelasan mengenai bahan hukum primer. ${ }^{8}$ dalam penelitian ini, penulis menggunakan buku-buku, literatur karya ilmiah para ahli hukum, hasil penelitian, jurnal, dan lain sebagainya yang berkaitan erat dengan bahan hukum primer dan isu hukum yang dihadapi, sebagai referensi.

3. Bahan Hukum Tersier, yaitu bahan hukum yang memberikan petunjuk atau penjelasan mengenai makna dari istilah yang terdapat dalam bahan hukum primer dan sekunder, dalam penelitian ini penulis menggunakan kamus umum (KBBI) maupun kamus hukum, Ensiklopedia, Internet dan lainnya.

\section{Teknik Pengumpulan Bahan Hukum}

Pengumpulan bahan hukum penelitian ini lakukan melalui studi pustaka (library Research) adalah teknik pengumpulan data dengan mengadakan studi penelaahan terhadap buku-buku, literatur-literatur, catatan-catatan, dan laporan-laporan yang terkait dengan masalah yang dipecahkan.

\section{Teknik Analisis Bahan Hukum}

Penelitian ini bersifat deskriptif-analitis, yaitu suatu metode dalam penelitian status kelompok manusia, objek, set kondisi, sistem pemikiran, ataupun kelas peristiwa pada masa sekarang. Tujuan dari penelitian ini adalah untuk membuat deskripsi atau gambaran secara sistematis, faktual dan akurat mengenai fakta-fakta, sifat-sifat, serta hubungan antar fenomena yang diselidiki. ${ }^{9}$

\section{HASIL DAN PEMBAHASAN \\ Kriteria Kecakapan Bertindak Bagi Penyandang Disabilitas Autisme Menurut Hukum Perdata}

Kewenangan perdata atau privat sebagai hak asasi yang terikat dalam seseorang. Hak perdata ialah ciri-ciri orang yang tidak bisa lenyap atau hilang. Ciri-ciri itu baru akan hilang jika orang tersebut meninggal dunia. Hak perdata ialah kodrati yang sudah Tuhan berikan. ${ }^{10}$

Setiap manusia pribadi atau natuurlijke persoon sebagai subyek hukum yang memiliki hak dan sanggup mengamalkan haknya ditanggung oleh ketentuan hukum yang berlaku. Dalam hukum perdata, subjek hukum (persoon) terbagi menjadi dua, yaitu orang (natuurlijke

\section{${ }^{8}$ Zainuddin Ali, Op.Cit., Hal.25.}

9 M. Nazir, Metode Penelitian, Jakarta, Ghalia Indonesia, 2003, Hal. 54

${ }^{10}$ Abdulkadir Muhammad, Hukum Perdata Indonesia, Citra Aditya Bakti, Bandung, 2000, Hal 3-4 persoon) dan badan hukum (recht persoon). Jadi setiap penyandang hak dan kewajiban disebut sebagai subjek hukum, namun, tidak semua dari penyandang hak dan kewajiban tersebut mampu atau cakap untuk melaksanakan hak dan kewajibannya secara mandiri.

Secara subyektif, kecakapan bertindak adalah orang yang diperbolehkan bertindak dan menambatkan diri, yaitu mereka yang mampu melakukan tindakan (handelingsbekwaam) dan mampu bertindak sesuai konsekuensi hukum. ${ }^{11}$ Lebih spesifik, Pasal 1330 KUHPerdata telah merincikan bahwa : yang tidak mampu atau tidak sanggup melakukan pernyataan setuju ialah mereka yang masih kanak-kanak (belum cukup umur) dan berada pada pengampuan, dan juga diantara beberapa orang perempuan yang telah diikat dalam ikatan pernikahan.

Seseorang yang menyandang disabilitas autisme yaitu orang yang menderita suatu gangguan perkembangan mental yang terjadi pada bagian otak tertentu yang secara kualitatif berupa : persepsi, kecerdasan (kognisi), emosi, dan perilaku yang dialami seseorang sejak masa anak-anak (fase usia 6 bulan-3 tahun) sampai masa pertumbuhannya berakhir dan tidak menutup kemungkinan kondisi autistik itu berlanjut hingga fase usia dewasa.

Hal ini menunjukan bahwa secara implisit UUPD membenarkan sesungguhnya orang yang menyandang disabilitas autisme sebagai subyek hukum dan berwenang atas hak-hak keperdataan seperti manusia (natuurlijk persoon) pada umumnya.

\section{Hak Seseorang Yang Menyandang Disabilitas}

Pada bagian penjabaran untuk Pasal 4 huruf c UUPD dijelaskan bahwa autisme merupakah salah satu jenis disabilitas, yaitu disabilitas pada kemajuan yang mempunyai pengaruh terhadap kesanggupan korelasi (interaksi) sosial. Hak-hak seseorang yang menyandang disabilitas diatur dalam UUPD Pasal 9 yang menerangkan bahwa hak atas perlakuan adil dan perlindungan hukum untuk penyandang disabilitas.

\section{Pengampuan}

Pengampuan adalah kondisi pada seseorang (curandus) yang disebabkan oleh perilaku pribadinya teranggap tidak mampu atau di dalam berbuat hal tidak sanggup melakukan sendiri (pribadi) dalam lalu lintas hukum. Atas dasar hal itu, orang tersebut dengan keputusan hakim dimasukkan ke dalam golongan orang yang tidak cakap bertindak. Orang tersebut diberi wakil menurut Undang-undang yang disebut sebagai pengampu (curator). ${ }^{12}$

${ }^{11}$ Herlin Budiono, Asas Keseimbangan Bagi Hukum Perjanjian Indonesia, Citra Aditya Bakti, Bandung, 2006, Hal 110

${ }^{12}$ http://bhpjakarta.kemenkumham.go.id/layanan-
publik/pengampuan 
Dasar hukum dari pengampuan adalah KUHPerdata bab XVII pasal 433 yang kemudian diuraikan dalam pasal 434-461. Kriteria orang di bawah pengampuan menurut Pasal 433, yaitu: Seseorang yang sudah cukup umur (dewasa), yang kerap pada keadaan dungu, sakit jiwa (pikirannya tidak normal) atau buta, sudah sepatutnya ditaruh pada pengampuan, meski sesekali ia terkadang mampu melakukan sesuatu dengan akalnya.

\section{Akibat Hukum Yang Dilakukan Oleh Penyandang Disabilitas Autisme Menurut Hukum Perdata}

Sebagaimana yang telah dijelaskan sebelumnya, bahwa menurut Pasal 1320 KUHPerdata, diantara syarat sahnya perjanjian adalah kesanggupan atau kemampuan melaksanakan suatu perikatan. Selanjutnya dalam Pasal 1330 KUHPerdata juga telah diterangkan mengenai subyek hukum yang termasuk tidak mampu untuk melakukan pernyataan janji, yaitu orang yang masih kanak-kanak atau belum dewasa (genap 21 tahun) dan orang yang berada pada pengampuan. Namun, oleh sebab penyandang disabilitas autisme adalah manusia pribadi atau natuurlijke persoon, maka penyandang disabilitas autisme juga termasuk subyek hukum perdata seperti manusia lainnya, sehingga tetap memiliki hakhak keperdataan yang tidak dapat dicabut oleh hukum apapun sampai orang tersebut meninggal dunia.Oleh sebab itu dapat dikatakan bahwa penyandang disabilitas autisme adalah subjek hukum yang hanya memiliki hakhak keperdataan tetapi tidak memiliki kecakapan bertindak untuk menjalankan sesuatu yang diperbuat hukum.

Pasal 1320 KUHPerdata menentukan syarat bahwa diantara beberapa pihak sebagai subyek hukum yang akan melakukan perjanjian patut patuh terhadap kriteria kesanggupan (kecakapan) berdasar aturan hukum, diantaranya ialah kesanggupan dalam melaksanakan perikatan, yang juga dapat diinterpretasikan sebagai kesanggupan (kemampuan) untuk menjalankan suatu yang diperbuat oleh hukum, dan salah satu syarat kecakapan untuk melakukan perbuat hukum adalah sudah cukup umur dan bukan berada pada pengampuan atau dengan kata lain subjek hukum (natuurlijk persoon) wajib mempunyai kemampuan untuk melaksanakan perbuatan hukum secara mandiri, sehingga para pihak dalam suatu hubungan hukum dapat saling mendukung hak dan kewajibannya sendiri.

Lalu, untuk memperoleh kepastian hukum tentang ketidakcakapan seseorang yang diduga sebagai penyandang disabilitas autisme diperlukan penetapan dari pengadilan negeri terlebih dahulu, sebagaimana yang diatur dalam pasal 32 UUPD. Oleh sebab itu, penyandang disabilitas autisme bisa saja melakukan perbuatan hukum sepanjang belum atau tidak dinyatakan sebagai subjek hukum yang tidak sanggup untuk melaksanakan perbuatan hukum oleh penetapan pengadilan negeri. Namun, sebaliknya apabila seseorang penyandang disabilitas autisme telah dinyatakan tidak cakap oleh penetapan pengadilan negeri terkait, maka secara yuridis mengakibatkan perbuatan hukum yang dilakukan oleh penyandang disabilitas autisme sebelumnya itu dapat dinyatakan batal demi hukum oleh otoritas yang berwenang.

\section{SIMPULAN}

Bersumber dari hasil pengkajian pada penelitian ini, sehingga dapat disimpulkan bahwa:

1. Seseorang yang menyandang disabilitas autisme pada dasarnya ialah subyek hukum (natuurlijke persoon) yang memiliki hak-hak keperdataan seperti manusia lainnya. Tetapi, Orang yang menyandang disabilitas autisme ialah subjek hukum yang tidak menyanggupi ukuran kesanggupan (kriteria kecakapan) yang diatur Pasal 1330 KUHPerdata, sehingga ketidakcakapan itu mengakibatkan penyandang disabilitas autisme tidak menyanggupi diantara empat syarat yang diatur dalam Pasal 1320 KUH Perdata mengenai keabasahan suatu pernyataan janji yang harus dipenuhi secara menyeluruh oleh setiap subjek hukum dalam melakukan perbuatan hukum. Sehingga bisa disimpulkan bahwa dikatakan sebagai orang penderita dan mengalami disabilitas autisme adalah subjek hukum yang hanya memiliki hak keperdataan, tetapi tidak memiliki kecakapan bertindak untuk melakukan perbuatan hukum.

2. Secara yuridis, diperlukan penetapan dari pengadilan negeri terlebih dahulu untuk memperoleh kepastian hukum tentang ketidakcakapan seorang penyandang disabilitas autisme, sebagaimana yang diatur dalam Pasal 32 UUPD. Oleh sebab itu, penyandang disabilitas autisme bisa saja melakukan perbuatan hukum perdata, sepanjang tidak diterangkan tidak mampu melalui ketetapan pengadilan negeri. Namun, apabila penyandang disabilitas autisme tersebut telah diterangkan tidak mampu sesuai ketetapan pengadilan negeri terkait, maka konsekuensi yuridis dari perbuatan hukum perdata yang telah dilakukannya sebelum putusan itu diterbitkan dan diterima adalah dapat dinyatakan batal demi hukum oleh otoritas atau lembaga yang berwenang.

\section{Saran}

Adapun masukan yang bisa diberikan dari hasil kajian ini yaitu sebagai berikut :

1. Pada dasarnya, pemerintah telah berupaya mengakomodir perlindungan hukum bagi penyandang disabilitas autisme dalam UU No. 08 Tahun 2016 tentang Penyandang Disabilitas, UU No. 39 Tahun 1999 tentang Hak Asasi Manusia (UU HAM) dan Konvensi CPRD (United Nations Convention on the Rights of Persons with Disabilities) yang telah diratifikasi oleh pemerintah Indonesia. Meski demikian, mengingat bahwa secara 
kondisional /keterbatasan mental seseorang yang menyandang disabilitas autisme ialah orang yang tidak sanggup untuk melaksanakan haknya secara mandiri dalam kehidupan sehari-hari, maka peran aktif keluarga, kerabat, hingga lingkungan sosial tetap diperlukan oleh penyandang disablitas autisme, baik dalam bentuk pembinaan maupun dalam hal pengampuan, khususnya agar hak-hak keperdataan penyandang disabilitas autisme dapat terlaksana sebagaimana yang telah diatur dalam peraturan perundang-undangan yang berlaku.

2. Kemudian, agar terjadi persetujuan yang sah dalam hubungan hukum perdata, khusunya hukum perjanjian, maka para pihak perlu memperhatikan ketentuan Pasal 1320 KUHPerdata. Oleh sebab itu, sebelum mengadakan perjanjian dengan pihak yang disinyalir atau terindikasi sebagai penyandang disabilitas autisme, perlu dilakukan verifikasi terlebih dahulu tentang dugaan tersebut melalui diagnosa medis dan secara yuridis melalui penetapan pengadilan negeri. Sehingga, jika dugaan itu terbukti benarberdasarkan diagnosa medis dan penetapan pengadilan negeri, maka perjanjian dapat dilakukan melalui pengampuan atau perjanjian itu dapat untuk tidak dilakukan sama sekali.

\section{DAFTAR PUSTAKA}

Abdulkadir Muhammad. 2000. Hukum Perdata Indonesia, Citra Aditya Bakti, Bandung

Hartono, B., 2002. Aspek Neurologik Autisme Infantil. Seminar \& Work-shop on Fragile-X Mental Retardation, Autism and Related Disorders, Universitas Diponegoro, Semarang

Herlin Budiono, 2006. Asas Keseimbangan Bagi Hukum Perjanjian Indonesia, Citra Aditya Bakti, Bandung

http://bhpjakarta.kemenkumham.go.id/layananpublik/pengampuan

M. Nazir, 2003. Metode Penelitian, Jakarta, Ghalia Indonesia

M. Sugiarmin, 2005. Bahan Ajar tentang Anak Autis, Fakultas Pendidikan Luar Biasa Universitas Pendidikan Indonesia, Jakarta

Mukti Fajar dan Yulianto Achmad, 2007. Dualisme Penelitian Hukum Normatif dan Empiris, Cetakan IV, Yogyakarta, Pustaka Pelajar

Undang-Undang Nomor 19 tahun 2011 tentang Pengesahan Convention On The Rights Of Person With Disabilities (Konvensi mengenai Hak-Hak Penyandang Disabilitas)

Zainuddin Ali, 2009. Metode Penelitian Hukum, Jakarta, Sinar Grafika, Edisi ke -1, Cetakan ke-5 